\title{
Mobilizing Science in the Heartland: Iowa State College, the State University of Iowa, and National Science during World War II
}

\author{
JOANNE ABEL GOLDMAN
}

ONE YEAR after the end of World War II, historian James Phinney Baxter reflected on the unprecedented research programs that the U.S. government had supported during the war and noted that "except for the development of the atomic bomb this [the radio proximity fuse program] constitutes perhaps the most remarkable scientific achievement of the war. ${ }^{\prime 1}$ Scientists at both Iowa State College (ISC) and the State University of Iowa (SUI) played roles in these two "remarkable" scientific achievements. ISC chemists developed methods to purify uranium in large quantities and at reduced costs. Their effort was critical to the success of the Manhattan Project, which culminated in the construction of the atomic bomb. Across the state, at SUI, another war-related research program involved extensive study and testing of the variable time (VT) proximity fuse that improved its capabilities and subsequent effectiveness.

There are several parallels between the solicited research programs at SUI and ISC. For instance, both programs found

The research and writing of this article was supported in part by summer fellowships and a professional development leave from the Graduate College of the University of Northern Iowa, and by a research grant from the State Historical Society of Iowa.

1. James Phinney Baxter 3rd, Scientists Against Time (Boston, 1946), 222.

THE ANNALS OF IOWA 59 (Fall 2000). (C) The State Historical Society of Iowa, 2000. 
themselves in the business of production as well as research. ISC scientists purified uranium for the war effort, and SUI physicists tested and assembled fuses. However, differences in managerial models and in the ways the programs were integrated into the universities' administrations had more lasting implications than the similarities between the two programs.

After the war, when the federal government decided to continue to fund scientific research, it continued the contractual relationship with ISC that had proved so successful during the war. The wartime research program directed by scientist/manager Frank Spedding became the Ames Laboratory, and ISC administered the federal contract that supported it. The presence of a national laboratory on the ISC campus had a profound effect on the way the physical science departments grew in the 1950s and 1960s. Programs within those departments became closely integrated with the associated divisions at the laboratory. In contrast, the work at SUI was terminated at the war's end, and the national science program had little effect on the way the physics department developed. After the war, SUI strengthened its prewar programs and nurtured the interests and opportunities brought by new faculty. Little, if any, legacy or memory of the proximity fuse program remains at SUI.

Many historians have examined the partnership between the federal government and academia that developed during the two world wars and became institutionalized with the creation of national laboratories in the postwar period. ${ }^{2}$ This study,

2. Some of that vast scholarship that has been particularly relevant to this study is Richard Rhodes, The Making of the Atomic Bomb (New York, 1986); Larry Owens, "The Counterproductive Management of Science in the Second World War: Vannevar Bush and the Office of Scientific Research and Development," Business History Review 68 (1994), 515-65; Stuart W. Leslie, The Cold War and American Science: The Military-Industrial-Academic Complex at MIT and Stanford (New York, 1993); Amy Sue Bix, "Backing into Sponsored Research: Physics and Engineering at Princeton University," History of Higher Education Annual 13 (1993), 9-53; Rodney W. Nichols, "Federal Science Policy and Universities: Consequences of Success," Daedalus 122 (1993), 197-224; Leon M. Lederman, "Science: The End of the Frontier?" Science 251 (11 January 1991), 3-20; Robert W. Seidel, "A Home for Big Science: The Atomic Energy Commission's Laboratory System," Historical Studies in the Physical and Biological Sciences 16 (1986), 135-75; Nathan Reingold, "Science and Government in the United States Since 1945," History of Science 32 (1994), 361-86; Arnold Thackray, ed., "Science After '40," Osiris 7 (1992); and Peter Galison and Bruce Hevly, eds., Big Science: The 
which focuses on the wartime solicited research programs at SUI and ISC, complements that body of literature by providing two additional case studies that contrast two very different institutions with very different missions executing federal contracts during World War II in very different ways. Interestingly, the implications of the government's solicited research program at SUI and ISC run counter to the experiences at many other institutions. ${ }^{3}$ At neither ISC nor SUI did the solicited research program fundamentally change the character of the schools. Rather, the growth of the physical sciences at ISC was consistent with its land-grant mission from its inception. Similarly, the termination of the contract at SUI did not alter the trajectory of that institution either, but rather allowed it to return to its prewar agenda.

IOWA STATE COLLEGE had a particularly long tradition of involvement with federal programs. In 1864, just two years after Congress passed the Morrill Act, Iowa became the first state in the nation to take advantage of its provisions and awarded the grant to the Iowa Agricultural College. (In 1886, its name appeared in the college catalog as Iowa State College of Agriculture and Mechanic Arts; however, the state did not officially approve the name change until 1896.) The Morrill Act allowed federal and state governments to finance institutions of higher learning

Growth of Large-Scale Research (Stanford, CA, 1992). See also the three-volume History of the United States Atomic Energy Commission: Richard G. Hewlett and Oscar E. Anderson Jr., The New World, 1939-1946 (Berkeley, CA, 1990); Richard G. Hewlett and Francis Duncan, Atomic Shield, 1947-1952 (Berkeley, CA, 1990); and Richard G. Hewlett and Jack M. Holl, Atoms for Peace and War, 1953-1961: Eisenhower and the Atomic Energy Commission (Berkeley, CA, 1989). For particular laboratories, see Robert P. Crease, Making Physics: A Biography of Brookhaven National Laboratory, 1946-1972 (Chicago, 1999); J. L. Heilbron and Robert W. Seidel, Lawrence and His Laboratory: A History of the Lawrence Berkeley Laboratory (Berkeley, CA, 1989); Lillian Hoddeson et al., Critical Assembly: A Technical History of Los Alamos during the Oppenheimer Years, 1943-1945 (New York, 1993); Jack M. Holl, Argonne National Laboratory, 1946-1996 (Urbana, IL, 1997); and Michele Stenehjem Gerber, On the Home Front: The Cold War Legacy of the Hanford Nuclear Site (Lincoln, NE, 1992).

3. Joanne Abel Goldman, "National Science in the Nation's Heartland: The Ames Laboratory and Iowa State University, 1942-1965," Technology and Culture 41 (2000), 435-59. 
that provided programs of practical study in the agricultural and mechanical arts-thus creating land-grant colleges. In 1871 this mandate broadened to include coursework in "domestic economy," primarily for women. As a result, ISC established one of the first home economics programs in the country. ${ }^{4}$ Further federal support for agriculture and the mechanic arts (engineering) continued in the years that followed. In 1888, just one year after the Hatch Act authorized the establishment of agricultural experiment stations in the land-grant colleges, ISC's agricultural experiment station was founded. This federal-state-college partnership continued into the twentieth century: the state legislature provided for an engineering experiment station in 1904, agricultural and home economic extension services in 1906, and engineering extension in 1913. Although initially each of these facilities was supported with state allocations, the Smith-Lever Act of 1914 provided federal support for extension programs at those institutions supported by the Morrill Act.

Indeed, a partnership between the federal and state governments and ISC distinguished its particular pattern of growth and development. SUI, on the other hand, was neither conceived in this tradition nor did it develop strengths in agriculture or the mechanical arts as ISC did. Rather, the state legislature, together with early administrators, sought to balance classical with practical education at SUI. ${ }^{5}$ The department of chemistry and natural philosophy played a key role in achieving this goal. In the 1860s, the department attracted national and international attention as it pioneered laboratory-based science education. ${ }^{6}$ In 1888 the physics department broke off from the department of chemistry and natural philosophy, and during the next eighty years its international prominence fluctuated as the identity of the department and the university evolved. A significant turnover in faculty in the early 1920 s provided an opportunity to introduce new blood and new interests. While acoustics continued to be

4. Earle D. Ross, A History of the Iowa State College of Agriculture and Mechanic Arts (Ames, 1942), 130-31, 287.

5. John C. Gerber, A Pictorial History of the University of Iowa (Iowa City, 1988), 25-28.

6. James P. Wells, Annals of a University of Iowa Department: From Natural Philosophy to Physics and Astronomy (Iowa City, 1980), 35-40. 
an important area of research, new physicists brought interests in materials research, particle-wave theory, and nuclear physics to the department. Its reputation soared during the interwar years, when department chairman George W. Stewart committed to showcasing the department. Preeminent physicists from the United States and Europe added SUI to their itineraries when touring the Midwest. Furthermore, the representation of university physicists at scholarly meetings complemented their prolific publication record and sustained the department's visibility in national and international circles.

By contrast, before World War II the primary mandate of the physical sciences at ISC was to complement the university's emphasis on agriculture and engineering. As such, both the physics and chemistry departments had an applied rather than theoretical thrust. Chemistry was the larger of the two programs and offered the M.A. and Ph.D. degrees. Physics had an applied physics graduate program but did not develop a general one until the $1950 \mathrm{~s}^{8}$

Both ISC and SUI enthusiastically supported U.S. involvement in World War I, and the federal government called on the institutions' strengths to serve military needs. They mobilized the agriculture and engineering programs at ISC for research and recruited prominent scientists from SUI to join federal research programs at various laboratories. At ISC, the agricultural experiment station, along with the departments of home economics, botany, bacteriology, and zoology, examined issues of food preservation and developed procedures to increase food production. Engineering faculty and staff addressed problems of military communication, mapping, camp construction, and fuel conservation. ${ }^{9}$

In addition to the mobilization of campus research programs, several ISC faculty members resigned their college posts

\section{Ibid., 100-101, 110-14.}

8. In addition to the descriptions of these programs in the college and university catalogs, see "Exhibits in Report to President on Graduate Study in Physics at the Two State Institutions," file 95, box 136, Hancher Papers, University of Iowa Archives, University of Iowa Libraries, Iowa City; Gerber, Pictorial History, 130; Wells, Annals of a UI Department; and Ross, History of ISC, 140, 141, 158-59.

9. Ross, History of ISC, 312. 
to enlist in military research programs. Anson Marston and T. R. $\mathrm{Agg}$, the then current and future deans of engineering, joined federal research programs, and bacteriologist Max Levine assumed command of a French laboratory. Similarly, SUI physicist George W. Stewart and psychologist Carl E. Seashore served on the National Research Council, which President Wilson had authorized in 1916 to coordinate the efforts of scientists in the military's interest. Seashore helped develop the pitch-range audiometer and diagnostic tools for wireless operators. Stewart worked in laboratories in Washington, D.C., and Pensacola, Florida, to improve methods to detect aircraft and submarines. On his home campus, he, together with colleague H. L. Dodge, developed microphones to help detect airplanes. Other colleagues took leaves to serve the nation at U.S. Army laboratories. F. C. Brown joined the Ordnance Department in Washington, D.C., to work on bomb ballistics and light reflection problems; L. P. Sieg addressed aviation-related issues.

During World War II the federal government stepped up its efforts to support scientific research for the military. In 1940 a group of the country's most prominent scientists, alarmed by America's unpreparedness for war and Germany's advances in Europe, prodded President Roosevelt to create the National Defense Research Committee (NDRC). Vannevar Bush, head of the Carnegie Institution and the National Advisory Committee for Aeronautics, became its director. Through the NDRC, Bush mobilized academic scientists on many different fronts to carry out research programs with military applications. Although some of those scientists joined research teams at government installations, Bush expected most to remain at their home institutions to keep academia intact and to capitalize on existing facilities. ${ }^{10}$

The government scientists addressed a multitude of problems. Because the need for scientific research was urgent, programs grew where space, personnel, and equipment were available until optimal facilities could be created. Eventually, new laboratories in Oak Ridge, Tennessee; Hanford, Washington; and Los Alamos, New Mexico, were built to accommodate the

10. Baxter, Scientists Against Time, 19, 20; Hewlett and Anderson, The New World, 25. 
demands of the multifaceted scientific program. Until those laboratory complexes could be built, however, research began at existing facilities. Indeed, eminent scientists from across the country joined teams of scientists at the University of Chicago, Columbia University, and the University of California at Berkeley to direct different aspects of the atomic energy research program. The government also solicited industrial and private laboratories. It contracted with the Carnegie Institution's Department of Terrestrial Magnetism, for example, to coordinate early research on the proximity fuse. In addition to creating those centers of scientific research, subcontracts were let to other academic and corporate laboratories when their facilities or personnel could serve the national programs. Contracts between the NDRC and the host institution delineated expectations and the terms of compensation but did not specify how the institution should carry out its mission. Rather, the means employed to execute the terms of the contract were left to the discretion of the contractor.

In 1941 President Roosevelt created the Office of Scientific Research and Development (OSRD) to subsume the NDRC and appointed Bush as its director. Within this new organization, the NDRC continued to support scholarly research under the direction of James B. Conant. Two of its earliest initiatives, the atomic and proximity fuse programs, involved scientists at SUI and ISC directly.

IN 1942, the OSRD recruited Arthur H. Compton, University of Chicago physicist and Nobel laureate, and authorized him to organize a metallurgical laboratory as part of the OSRD's atomic research program. At the University of Chicago, he assembled a group of scientists to examine several aspects of atomic energy. Compton learned of ISC chemist Frank Spedding's expertise in rare earth chemistry and invited him to join the metallurgy group. ${ }^{11}$ Spedding had received his Ph.D. in

11. Rare earths, or lanthanides, include 15 elements with atomic numbers 57 through 71. Several interesting properties make them noteworthy. First, most lanthanides are nearly indistinguishable chemically since the outermost electron shells, which control most chemical interactions, are filled. While the number of electrons in the outermost shell usually distinguishes a particular 
chemistry from Berkeley in 1929, followed by a postdoctoral fellowship there, a Guggenheim fellowship in Europe, and a Baker fellowship at Cornell University. During those years Spedding's reputation as a first-rate spectroscopist and rare earth chemist grew. In 1937 he joined the faculty at ISC complete with tenure, as he insisted. ${ }^{12}$

Although Compton expected Spedding to assemble a chemistry division within the metallurgical laboratory in Chicago at some point, he allowed Spedding to initiate a research program at ISC, where the equipment and talent were already assembled. The continued success of the group at ISC forestalled any move to Chicago, and the program remained at ISC throughout the war.

Spedding drew staff from ISC's chemistry and physics departments. Chemists Harley A. Wilhelm, John A. Wilkinson, and Harvey Diehl, physicist R. E. Rundle, and graduate students C. F. Gray and Adrian Daane held key positions. With the support of ISC's president, Charles E. Friley, faculty and students maintained their academic positions while working on the project. To compensate the college, Spedding negotiated the government's assumption of a prorated part of their salaries proportionate to their involvement in the federal program. ${ }^{13}$ In addi-

element from its neighbor, for rare earths, it is the number of electrons in their $4 \mathrm{f}$ shell that varies. A second, related reason for great interest in the rare earths is that pronounced magnetic properties arise from the filling of the $4 \mathrm{f}$ shell, leading to magnetic materials of great technological importance. There is a natural association of rare earths with the actinide elements such as uranium and thorium. In fact, the actinides are also chemically similar to the lanthanides except that now the $5 \mathrm{f}$ rather than the $4 \mathrm{f}$ shell is filled in the series. In natural ore, rare earths are always found as impurities with uranium and thorium. Since the latter elements were desired in an extremely pure form for the project, these contaminants had to be removed. In addition, when uranium and plutonium undergo nuclear fission, rare earths are generally found among the fission products, again prompting interest in their identification. See F. H. Spedding, "Progress in Rare Earth Chemistry" (n.p., n.d.), in the Spedding Papers at the Iowa State University Archives, Ames; F. H. Spedding, "The Rare Earths," Scientific American 185 (November 1951), 26-30; Karl A. Gschneidner Jr., Rare Earths, The Fraternal Fifteen, A World of the Atom Series Booklet (Washington, DC, 1966), 1-8.

12. Harry Svec, Prologue, Handbook on the Physics and Chemistry of Rare Earths, vol. 11, ed. K. A. Gschneidner Jr. and L. Eyring (New York, 1988), 8.

13. Contract No. W-7405 eng-7, 14 May 1945, Department of Energy Records of the History Division, Washington, DC. 
tion, he tapped professional networks to recruit scientists: I. B. Johns, an ISC Ph.D., returned from Monsanto Chemical in Boston; Wayne Keller was recruited from Cornell University, Adolf Voigt from Smith College, and Amos Newton and W. H. Sullivan from industry. During the war, the scientific staff alone exceeded one hundred.

Spedding directed the Ames Project, and Wilhelm and Johns became associate directors of the laboratory-Wilhelm managed the metallurgical programs and Johns developed a plutonium research division. ${ }^{14}$ The program's structure assumed a pyramidal form, and as the group expanded, its hierarchy became more apparent. By mid-1942, section chiefs directed specific research programs under the guidance of the two associate directors. Although some early industrial research and development efforts adopted this model, it was a relatively new type of organization for American universities, where, in general, comparatively small research groups pursued studies independently. ${ }^{15}$

This pyramidal organizational model was particularly well suited to the solicited research program. It clarified relationships and authority and facilitated the integration of research efforts that kept work in Ames progressing despite Spedding's frequent absences. That was important since he spent only half of each week in Ames and the other half in Chicago to coordinate ISC's program with the metallurgical laboratory. On Sunday mornings, Spedding met with the senior members of the group to review the past week's work and plan for the next week's effort. Spedding's colleague Harry Svec noted that "the breadth of the work is such that the coworkers were many but the inspiration and drive to do the work was largely due to Spedding's perception of what needed to be done, how it should be done and when it should be accomplished."16

14. Johns moved this plutonium program to the Los Alamos Laboratory in 1944. 15. In the late 1920s and 1930s, Ernest Orlando Lawrence's laboratory at Berkeley became the prototype of this type of organization for academic research. Under Lawrence's leadership, assistant directors, crew chiefs, and other designated group leaders directed particular lines of cyclotron research. The hierarchical structure defined relationships, responsibility, and authority, presumably increasing the pace and efficiency of directed research. Robert W. Seidel, "A Home for Big Science," 39.

16. Svec, Prologue, 7. 
The highly classified nature of the work further strengthened Spedding's authority. Even ISC's president, Charles Friley, was ignorant of the details of the work until he received the necessary security clearances several weeks after the project began. Nevertheless, from the beginning Friley wholeheartedly supported the war-related research work. ${ }^{17}$ He ordered the administration to fully comply with any of Dr. Spedding's requisitions. On at least one occasion, this sweeping mandate caused concern and contributed to the "Whiskey Barrel Incident," one of the most talked about local anecdotes from this period of ISC's history. ${ }^{18}$

Friley's attitude towards the solicited research program extended well beyond support for Spedding's work. Perhaps most importantly, Friley's nonintervention policy gave Spedding extraordinary authority and autonomy to manage the program. Spedding negotiated contracts with Washington, developed the laboratory in Ames, and directed the research program, albeit within the guidelines set by Compton.

Despite initial plans to capitalize on Spedding's rare earth expertise, the more urgent problem was how to obtain a high purity uranium in bulk quantity, so the rare earth program was put on hold. By September 1942, the group had developed the "bomb reduction method" to purify uranium. ${ }^{19}$ That process

17. Earle D. Ross, The Land Grant Idea at Iowa State College: A Centennial Trial Balance, 1858-1958 (Ames, 1958), 210-26.

18. When the Ames group needed containers to dispose of the uranium slag, Wayne Keller, senior chemist, suggested that exhausted whiskey barrels might work well. In Keller's hometown in Kentucky, the Hiram Walker Whiskey Company regularly used barrels during the process of aging whiskey but had no use for them after the liquor was bottled. They would be perfect receptacles for the waste. Spedding submitted an order for 1,000 barrels. Inadvertently, the typist did not specify empty barrels. In addition to any moral misgivings of fulfilling such a request, state law restricted liquor sales, which left the purchasing office in a quandary. In light of the presidential order for steadfast compliance, the office called Spedding at 6:30 a.m., and he rectified the error. Reportedly, once the barrels were delivered, students flocked to the railroad to unload them. Apparently word had spread that when cocked just so, a cup of whiskey could be retrieved from each barrel. This story has been told many times with some variation. This version was taken from the newsletter for the employees of Ames Laboratory, Insider (December, 1992), 4.

19. Until that time, production of uranium was extremely difficult, and the product when made was usually highly contaminated. By breaking with con- 


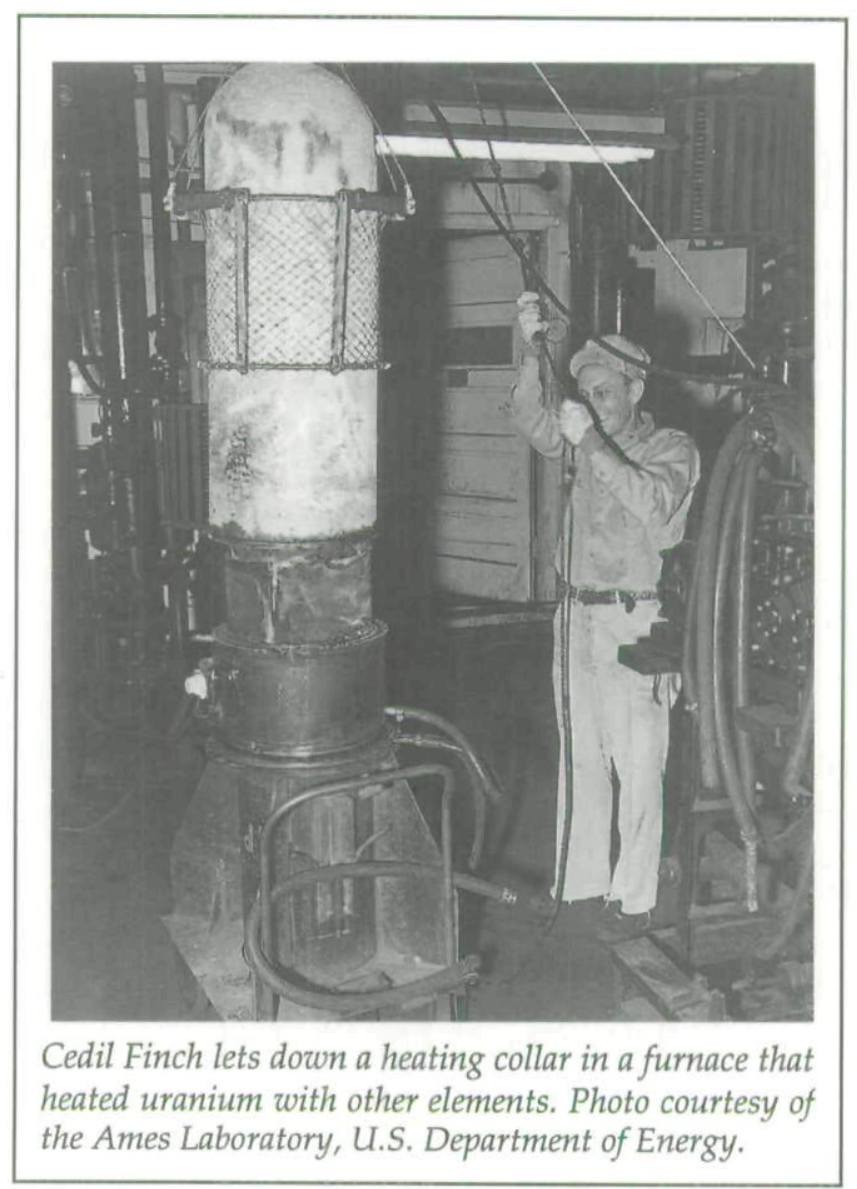

yielded the metal at a degree of purity not achieved earlier, at reduced costs, so uranium production became the group's top priority. By the following month, they were purifying an average of 100 pounds of uranium per week, and the rate increased steadily. The metal was sent to Chicago, where scientists assem-

ventional assumptions about uranium, Wilhelm's group overcame these problems. Rather than working with uranium oxide, they found that the reduction of uranium tetrafluoride with a salt, rather than hydrogen, in the graphite crucible they developed did indeed produce pure uranium. See "A Brief History of the Atomic Energy Project under the Direction of F. H. Spedding at Iowa State College," box IAR 1945-1946,1946-1947, Friley Papers, Iowa State University Archives. 
bled the uranium briquettes in a carefully defined matrix, with graphite as a moderator, and on December 2, 1942, successfully demonstrated the feasibility of a chain reaction. That demonstration, and its implications for the ultimate success of the Manhattan Project, stimulated an even more urgent need for the materials, keeping the Ames group in the production business, at least for the time being. ${ }^{20}$ In July 1943, Harley Wilhelm, Spedding's associate director, led a team that instructed scientists at the Mallinckrodt Corporation, the DuPont Corporation, and the Electrometallurgical Division of Union Carbide Co. to produce metal via the Ames process. However, until the work was effectively transferred to the private sector, the Ames operation carried the burden, producing more than two million pounds of metal by the war's end. ${ }^{21}$

After the demand for uranium calmed, Spedding's group applied the same techniques used in the production of uranium to thorium, beryllium, and cerium. Thorium was sought to fuel the breeder reactors that could supplement the expected shortfall in the availability of U-235. Beryllium and cerium were particularly suited to the crucibles that withstood the bomb reduction of thorium and plutonium, respectively. Furthermore, beryllium was found to be an effective moderator for nuclear reactions. Though never reaching the level of uranium production, significant quantities of these metals were produced by Ames scientists. ${ }^{22}$

Toward the end of the war, the group at ISC, in addition to its materials production, finally turned to the study of the rare earths, their initial charge. Although rare earths were so named because many believed that they were rare, they do, in fact, exist naturally in significant quantities. Nevertheless, even after they

20. After the success of the pile in Chicago, most of the uranium purified in Ames was shipped to Hanford, Washington, and Oak Ridge, Tennessee, for use in reactors there.

21. E. I. Fulmer, "History of Ames Project," unpublished report, 9 December 1946, 7-15, Spedding Papers, ISU Archives. See also Supplement No. 9 to Contract No. W-7405-Eng-7, effective date 12 January 1945, Department of Energy, History Division.

22. Fulmer, "History of Ames Project," 15-20; Hewlett and Anderson, The New World, 29, 286-87. 
were identified, they remained relatively neglected because separating the various rare earths from one another was extremely difficult. Prior to the work of Spedding's group, separating the "rarest" of these elements with any significant degree of purity required as many as 40,000 distinct operations. Indeed, some scientists spent their entire professional lives refining a rare earth to 99 percent purity. This labor-intensive process of separation produced only limited quantities. Therefore, the properties and usefulness of rare earth elements remained relatively unexplored. In 1945, Spedding, along with other members of his group, solved this bottleneck in rare earth research by exploiting a process that produced rare earths at 99.99 percent purity. ${ }^{23}$ The government authorized the construction of a pilot plant to separate the metals, and, until industry assumed production, ISC produced most of the purified rare earths available.

After the war, the solicited research program continued at ISC unabated. The study of the rare earths and thorium, as well as much of their production, dominated work in the years immediately following the war and continued well into the $1950 \mathrm{~s}^{24}$ ISC's leadership in rare earth research continues to this day through its Rare-Earth Information Center. ${ }^{25}$ The program that developed during the war created an institutional framework that became the foundation of the postwar solicited research program. The dominant features of that framework-Spedding's authority, the pyramidal model, and the close ties between ISC and the Ames Project-continued to characterize the laboratory in the postwar period.

IN CONTRAST to the situation in Ames, the solicited research program at SUI ended with the cessation of hostilities and of-

23. Fulmer, "History of Ames Project, 41-42, describes the process that was employed. See also Gschneidner, "Rare Earths," 6, 10-11; and Spedding, "The Rare Earths," 26.

24. Spedding, "The Operation and Scope of the Ames Laboratory of the Atomic Energy Commission," p.12, folder Speeches, 1960-1962, box Z, Spedding Papers.

25. This center provides a central databank with information on "collecting, storing, evaluating and disseminating rare earth information" to the technical and scientific communities. See their website at www.external.ameslab.gov/ric/ for more information. 
fered little in the way of long-term impact on the physics department at SUI. Rather than people and equipment being shared with the associated department, as was the case at ISC, the solicited research program grew increasingly distinct from the university, particularly as the project expanded. Moreover, no dominant figure emerged with significant authority or autonomy over either the laboratory or those departments associated with it. Instead, authority remained diffuse as the scientists in the program served several masters.

The proximity fuse program set out to maximize the destructive impact of weapons, particularly those targeting aircraft. These radar devices were placed in shells, rockets, and bombs to trigger an explosion at a predetermined distance from the target. Although this optimum range could be calculated, variables in the manufacture, setting, timing, and environment rendered the fuses unpredictable. Work on this problem had been under way for some time both in the international community and in the U.S. Navy's Council for Research, but little progress had been made. One of the NDRC's first initiatives was to begin a fuse research program at the Department of Terrestrial Magnetism (DTM), directed by Merle A. Tuve, in Washington, $\mathrm{DC}^{26}$

In 1940 Tuve consulted Alexander Ellett, professor of nuclear physics at SUI. Soon after, Ellett joined the program full time. Almost immediately, Tuve and Ellett decided to divide the program into two principal efforts. Tuve focused on shells and moved his operation to Johns Hopkins University. There he established what would later become the Applied Physics Laboratory. Ellett assumed direction of that part of fuse development associated with bombs and rockets and set up his laboratory at the National Bureau of Standards (NBS) in Washington, DC. It is not clear why Ellett moved to the NBS rather than remain at SUI. Proximity to Tuve may have been the initial consideration. Nevertheless, a year and a half later, he called on his old colleagues to set up a small branch laboratory at SUI. Although work was subcontracted to Iowa, Ellett remained at the NBS. His former student and colleague James A. Jacobs directed the

26. Baxter, Scientists Against Time, 221-42. 


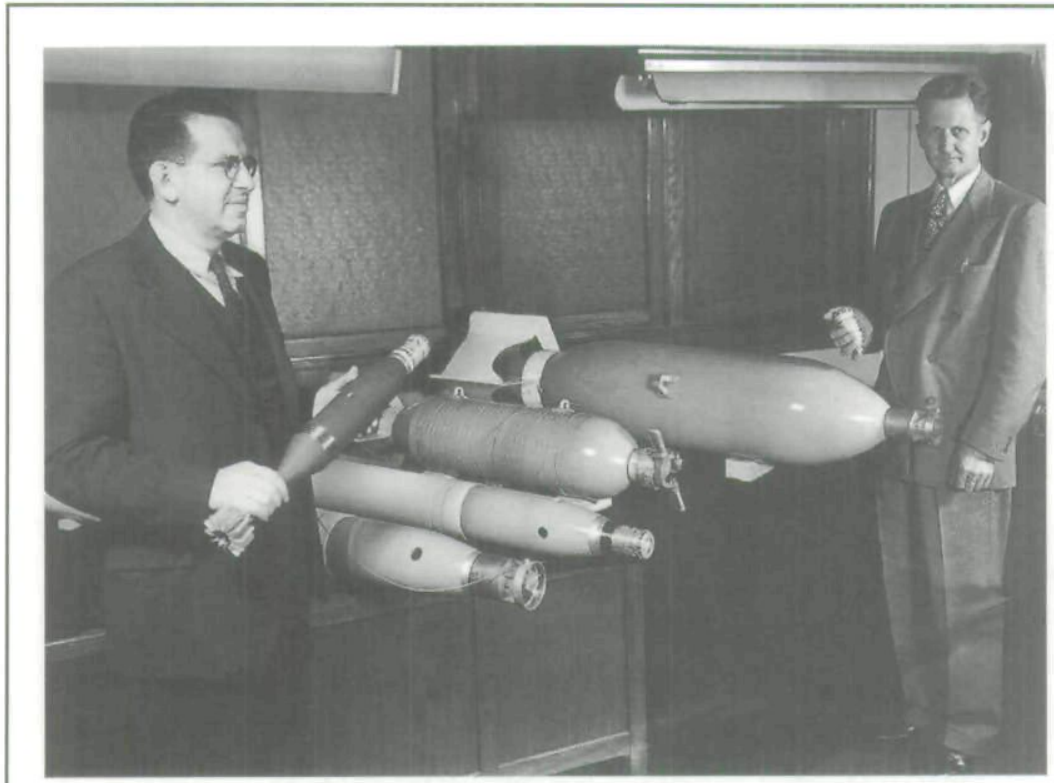

The National Bureau of Standards designed different types of radio proximity fuses to mount on different weapons. Harry Diamond, chief of the NBS Ordnance Development Division (left), holds the mortar fuse mounted on an $81 \mathrm{~mm}$ mortal shell. Alexander Ellett, chief of Division 4 of the National Defense Research Council (right), holds an unmounted mortar fuse. Photo (1946) courtesy of the National Institute of Standards and Technology Administration, U.S. Department of Commerce.

program on site, and associates from the departments of physics and engineering assisted him. ${ }^{27}$

Initially, this branch laboratory identified and corrected design problems and developed equipment to test the electronics of the fuses, but the laboratory's charge grew steadily. In June 1944 the lab began field-testing to examine the effect of storage environments on the fuses. In February 1945, when the NDRC authorized a six-fold expansion, the project was renamed the Physics-Engineering Development Program (PEDP). A pilot

27. Jacobs earned his Ph.D. from the University of Iowa in 1941 and became an assistant professor of "nuclear problems" there the following year. The most complete treatment of the program developed at the University of Iowa is Wells, Annals of a UI Department, 141-66. 
plant provided for design improvements to be incorporated into the manufacturing process, and large-scale production of the prototypes followed. While research continued in Iowa City, both on and off campus, the PEDP also leased a site north of Clinton, Iowa. This isolated, secure, but accessible location suited the volatile nature of the expanded program. Initially, production goals were set at 50 to 75 units per day, but by June 1945 the government's requisition reached 100 fuses per day, a mere fraction of the millions of fuses that the government hoped to produce at facilities throughout the country. ${ }^{28}$

In March 1945 the NDRC sent Lucien L. Friez to Iowa to manage the expansion and the day-to-day operations of the laboratory, allowing Jacobs to focus on "important duties in the technical section" of the project. ${ }^{29}$ Friez, who had extensive experience in both aeronautical equipment and government work, was an appropriate choice for general manager. Since 1919 he had managed the family business, which, after World War I, supplied aviation instruments to the Air Corps as well as commercial airports. In 1930 he merged his company with Bendix Aviation and ran the new conglomerate as president and general manager until 1944. In that capacity, he developed "additional and new facilities, new machine tools for quantity production, new and more expanded production set-ups, new assembly lines, rigid inspection procedure, and all the other production methods and production devices required for speed and lower costs. ${ }^{\prime 30}$ The government recruited Friez because his expertise and experience was so appropriate to the proximity fuse program and, in particular, the current phase of expansion.

In theory, Friez and Jacobs complemented one another in the management of the PEDP: Jacobs directed scientific and technical research, and Friez incorporated those improvements into the fuses at the workbench. However, the real picture was much

28. Minutes, PED Committee, 22 June 1945, file 154, box 115, Hancher Papers. Baxter, Scientists Against Time, 233, notes that at peak production two million fuses per month were manufactured "with 300 different companies and 2,000 different plants at work."

29. Virgil Hancher, SUI president, to Ellett, 24 March 1945, file 154, box 115, Hancher Papers.

30. Friez to F. M. Dawson, Dean of Engineering, 16 February 1945, ibid. 
more complex. While Jacobs apparently directed the scientific program, albeit in consultation with Ellett, Friez had little independent authority. The general manager received orders from three sources: the federal government, the university president, and the Physics Engineering Development Committee (PED Committee). Alexander Ellett and John S. Rinehart, technical aide to Division Four of the NDRC, articulated the federal interest. On behalf of the government, they negotiated the contract that defined the scope, goals, size, schedule, and budget of the program. Furthermore, they coordinated the work in Clinton and Iowa City with other aspects of the proximity fuse research program under way at laboratories in Maryland and Florida. ${ }^{31}$

In contrast to Friley at ISC, SUI president Virgil Hancher assumed a very active role in managing the PEDP. He was central to negotiations of the initial contracts, the subsequent expansion, and the leasing of downtown and proving ground properties. ${ }^{32}$ At the same time, Hancher defined boundaries that firmly distinguished the university from the military research project it administered. In March 1944, George Stewart, head of the Department of Physics, confirmed that "this project has no connection with either the basic research or the teaching of the University. The University is conveniently the contractor." ${ }^{\prime 33}$ During negotiations the following year, Hancher reiterated that Ellett's proposal "would not bring the project within any college or department, but would make it an independent affair responsible only to the President's office. ${ }^{134}$

31. Memorandum, Allin Dakin to Virgil Hancher, Subject PED Organization and Operation, n.d.; Rinehart to Hancher, 8 March 1945; Irvin Stewart, contracting officer, OSRD, to Hancher, 6 April 1945; transcript of telephone conversations between Dawson and Rinehart, 24 March 1945, and between Friez and Rinehart, 21 August 1945; Minutes, PED Committee, 22 June 1945, all in Hancher Papers.

32. Ibid. For insights into Hancher's personality and management style, see Stow Persons, The University of Iowa in the Twentieth Century: An Institutional History (Iowa City, 1990), 145.

33. G. W. Stewart to Hancher, 31 March 1944, file 183, box 93, Hancher Papers.

34. Virgil M. Hancher, "Memorandum: Proposal for Additional War Research, Physics-Engineering Proposal By Ellett," 27 January 1945, file 115, box 154, Hancher Papers. 
The PED Committee ostensibly represented the university's interests. It consisted of the engineering dean, Francis Dawson; the administrative dean, Allin Dakin; the liberal arts dean, Harry Newburn (replaced by Earl McGrath in the summer of 1945); the chair of the physics department, George Stewart; and the university's business manager, Fred Ambrose. They supervised the PEDP, set "general" policy, leased properties, directed Friez, particularly in his dealings with the OSRD, and integrated the different divisions of the program. ${ }^{35}$

The manner in which the PEDP was organized prevented any concentration of authority that could effectively alter the course of the physics department. Furthermore, because Friez had no personal or professional ties to the university, only a limited bond between the PEDP and the physics department developed. Moreover, Hancher introduced personnel policies that kept the project distinct from the university. Faculty who chose to become part of the PEDP were forced to resign their positions within the university and forgo their rights to tenure, retirement, and benefits. This could be circumvented with approval of the dean and president, but only if the scientist agreed to work at the prevailing university salary rate, rather than the premium rate paid by the PEDP. If they agreed to those terms, faculty members could take a leave from the university, rather than resign, and retain their academic status. The PED Committee approved this, as well as most of Hancher's initiatives, before they were implemented. ${ }^{36}$

To carry out its mandate, the PEDP was divided into four divisions: research; model; production; and administration, security, and maintenance. Friez integrated the work of these divisions, but he did not direct their internal operations. In a manner becoming increasingly characteristic of large-scale research,

35. Transcript of telephone conversation between Ellett and Hancher, 27 January 1945. See also Minutes, PED Committee, 22 March, 16 April, 26 May, 7, 14, 22, and 27 June, and 21 September 1945, file 154, box 115, Hancher Papers.

36. This policy was enacted despite the protests of Dean Dawson and Department of Physics Chair George Stewart. Hancher to Dawson 14 May 1945; Dawson and Stewart to Hancher, 15 May 1945; and Hancher to Dawson and Stewart, 17 May 1945, all in file 154, box 115, Hancher Papers. Nevertheless, the PED Committee approved the plan and it became policy on 26 May 1945. See Minutes, PED Committee, 26 May 1945, file 154, box 115, Hancher Papers. 
hierarchies within each section carried out their respective mandates. Division heads coordinated the work of group leaders who, in turn, directed staffs to carry out particular responsibilities. In the research division, Jacobs, assisted by three "staff members," determined the scientific, development, and engineering programs that were carried out by associates and assistants ranked according to their education and experience. The model division of the PEDP developed prototypes based on the improvements that the research division introduced. A master instrument maker directed mechanical and electronic instrument makers and numerous technicians to execute this charge. Once the prototypes passed inspection, the production division assumed responsibility for their manufacture and assembly. Friez managed that operation directly. The production manager answered directly to him and, in turn, supervised the work of the production foreman, assembly foreman, productionplanning superintendent of maintenance, and chief inspector. Each of those department heads managed a technical staff to carry out their assignments. Even the administration, security, and maintenance division assumed this hierarchical model. A junior supervisor managed the office, and the secretaries supervised the clerks, typists, and stenographers. Similarly, the transportation clerk directed the work of his assistants. The purchasing, timekeeping, storekeeping, and janitorial staffs were relatively small and less formally organized. ${ }^{37}$

Despite this elaborate organization, the PEDP never reached optimum productivity. The NDRC identified chronic understaffing as the crux of the problem, and by the end of June 1945 called for a 50 percent increase in the staffs of the research division as well as the administration, security, and maintenance division. The situation in the model and production divisions was even more serious. Estimates based on the desired productivity of 100 units per day called for a staff of 148 , yet only 47 were employed. Rinehart expressed his frustration in a letter to Friez. Stating that "your laboratory testing group suffers seriously

37. See Summary of Personnel Requirements, Physics Engineering Development Project, submitted to the PED Committee and included in their minutes, 27 June 1945, file 152, box 143, Hancher Papers; PEDP Job and Salary Scale and Job Descriptions, file 154, box 115, Hancher Papers. 
from lack of personnel and facilities," he ordered that resources be consolidated to maximize production. ${ }^{38}$ Despite the effort, the OSRD never fully realized its goals.

On August 20,1945, soon after the bombing of Pearl Harbor, Rinehart telegraphed Hancher and ordered him to "limit further work under contract . . . to preparation of final report and normal termination activities STOP Cease other work at once STOP Terminate subcontract and place no further orders except to extent that you or a subcontractor wish to continue for your own account and work in process STOP Telegraph similar instructions to all subcontractors and suppliers STOP Letter and instructions follow." ${ }^{139}$

Work stopped and termination procedures followed. Technical equipment and office supplies were sold, final reports were written, and property leases were settled. Former SUI physicist Alexander Ellett never returned to the university but became director of research for the Zenith Corporation. During the war, the federal government had engaged Zenith in proximity fuse research, and the government planned to continue those contracts after the war. ${ }^{40}$ Friez resigned, effective October 1, 1945, left Iowa City, and designated Professor Jacobs to complete the laboratory's shutdown with a skeletal staff. Afterwards, Jacobs returned to full-time employment at the university and assumed leadership of the nuclear physics program.

THE PEDP was an effort by SUI to support the national war agenda. There were no long-term plans for it to serve the university's interests or objectives; in fact, every effort was made to limit its influence. The PED Committee administered the program for the university and maintained the distance between them. After the war, the project was terminated with little impact on the fate of the physics department, at least in part be-

38. Rinehart to Friez, 27 July 1945; Employment summary of PEDP, in Summary of Personnel Requirements, file 152, box 143, Hancher Papers.

39. Copy of Western Union telegram, 20 August 1945, file 152, box 143, Hancher Papers.

40. Transcript of telephone conversation between Rinehart and Friez, 21 August 1945, file 152, box 143, Hancher Papers. 
cause no one in the program emerged with the ambition, ability, and record of achievement to assume a place in the postwar national science program, except perhaps for Ellett, but he had resigned.

In contrast, at ISC Spedding sought to confirm his continued dominance over the atomic research program at ISC after the war. Spedding successfully lobbied to create a new mechanism of management through which he could mediate the relationship between ISC and the national research program he anticipated. On November 1, 1945, he realized his dream; the Iowa State Board of Education established the Institute of Atomic Research (IAR) and named Frank Spedding its director. From its inception, the IAR managed the federal contracts that continued to flow to Spedding's group even after the war. ${ }^{41}$

Indeed, the government grew concerned about maintaining its preeminence in the field of atomic energy after the war and therefore continued to support research in that area. In 1946 it authorized the creation of the Atomic Energy Commission (AEC) to oversee that effort. The AEC built three national laboratories: Clinton National Laboratory in Oak Ridge, Tennessee; Argonne National Laboratory located outside Chicago, Illinois; and Brookhaven National Laboratory, built on the sight of a military installation, Camp Upton, in Yaphank, New York. In addition, the AEC established other "centers of research," one of which was designated the Ames Laboratory. ${ }^{42}$ Adopting the model that proved so successful during the war, the AEC contracted with universities and industries to manage the labs and "carry out the principal research operations." ${ }^{43}$ The AEC designated ISC as the contractor-operator of the Ames Laboratory and appointed

41. Harold V. Gaskill, director of Division of War Research at ISC, to Charles E. Friley, ISC president, 3 October 1945, Friley Papers; Friley to Drs. J. B. Fisk and R. W. Warner, directors of Research and Engineering respectively, AEC, 3 February 1948, carbon copy in Spedding Papers.

42. Other laboratories established included Los Alamos Scientific Laboratory; the Radiation Laboratory at the University of California, Berkeley; the Knolls Laboratory at Schenectady, NY; and, to some extent also, the laboratories connected with the AEC's Hanford and Oak Ridge production plants. See Atomic Energy Commission, Fifth Semi-Annual Report, January, 1949 (Washington DC, 1949), 67.

43. AEC, Fifth Semi-Annual Report, January, 1949, 64. 
Spedding its director. Similarly, the AEC solicited a research program that continued to explore lines of research begun during the war, in particular the study of the transuranic elements and "fundamental studies on certain types of chemical separation processes ... [and the] recovery of uranium and thorium..$^{\prime 44}$

The Ames project and, subsequently, the Ames Laboratory had a critical impact on the way those departments associated with it developed and the way Spedding's influence within ISC expanded. To be sure, Spedding focused the laboratory's energy on problems outlined by the federal government. However, Spedding's research interests and those of the laboratory he assembled were compatible with the national research agenda. Solid state and nuclear research, with particular emphasis on the rare earths, remained central to the solicited research program, and the resources that the government provided allowed those programs to grow at ISC. Because the time and salary of new appointments were split between the Ames Laboratory and ISC, the hiring power of those shared programs grew, further strengthening the departments of chemistry and physics. ${ }^{45}$ Equipment and space provided by the government increased the appeal of ISC's facilities. For example, ISC allowed overhead funds paid by the government to be allocated for the construction of a synchrotron in 1950, and the government financed a nuclear reactor installed on campus in 1961. Both machines supported the materials research program then under way. In 1948 the federally funded metallurgy building added about 65,000 square feet of space to the crowded ISC campus.

In contrast, at SUI, the solicited research program had little impact on the character of the physics department after the war. After the OSRD dismantled the proximity fuse program, the physics department resumed its prewar agenda. A small but growing emphasis on nuclear studies had developed in the

44. AEC, Third Semi-Annual Report, February 2, 1948 (Washington, DC, 1948), 14.

45. The chemistry department entered a period of sustained growth between 1946 and 1959, when it grew from 18 to 51 faculty members. More than half of the new faculty held joint appointments in the department and the Ames Laboratory. A similar pattern was apparent in the physics department. It had 16 faculty members in 1946, 33 in 1959, and 41 in 1965; three-quarters of them held joint appointments. See ISC catalogs. 
1930 s. $^{46}$ Ellett had led this effort, but with his departure, Jacobs became its moving force. The university initially supported the growth of the program. When department chairman Stewart retired in 1946, the university recruited Louis A. Turner, an accomplished nuclear physicist, to head the department, and during his first year the university authorized two new faculty appointments in nuclear physics. However, faculty alone could not build a first-rate nuclear program. ${ }^{47}$

The existing equipment for the nuclear group was dated and in disrepair, and the university failed to budget to upgrade it. Five years of neglect, while Jacobs and his group were absorbed with the proximity fuse program, took its toll. A decade earlier, the Cockroft-Wilson accelerator had facilitated several theses, but its limited capabilities frustrated further research. A Van de Graaff linear accelerator better suited the needs of the group, and by the end of the 1930s Ellett had arranged for its purchase and installation. When, after the war, attention once again focused on making the Van de Graaff operational, the costs were staggering. The initial estimate of $\$ 30,000$ for installation was inadequate; the price now exceeded $\$ 100,000$. Turner's inability to raise the required funds indicated the limits of university support for the program. ${ }^{48}$ Frustrated, Turner left in 1950 to become the director of physics research at the Argonne National Laboratory.

In 1951 alumnus James Van Allen returned to chair his old department. During his tenure, the direction of the physics department changed dramatically. Van Allen had been trained under Ellett in nuclear physics and, in fact, had worked with Tuve at the Applied Physics Laboratory at Johns Hopkins University before returning to Iowa City. Soon after his arrival, however, he became interested in cosmic rays. Grant money and university support enabled him to develop a program in cosmic ray research during the 1950s. In 1957 it surpassed the nuclear program in funding and became the strongest program in the department. ${ }^{49}$

46. Wells, $128-31$.

47. Ibid., 151-60.

48. Atomic Energy Commission allocations in the 1950 s eventually enabled the department to make the necessary repairs of the Van de Graaff.

49. Wells, Annals of a UI Department, 167-203. 
STRIKING DIFFERENCES in the development of the research programs at ISC and SUI account for these distinct postwar legacies. At ISC, Friley welcomed the solicited research program and allowed Spedding extraordinary latitude to manage it. This, together with Spedding's ambition, personality, and capabilities allowed him to become a particularly strong scientist/ manager. The successes of the laboratory under his direction, both during the war and in materials and rare earth research afterwards, further secured his position. From that position, he effectively articulated the federal agenda to ISC and advocated ISC's interests to the government. He assembled a research laboratory that integrated the personnel, equipment, space, and interests of ISC's associated science programs and the solicited research program to the benefit of each.

In contrast, SUI's PEDP achieved only marginal success and never fulfilled the NDRC's goals of production. To the extent that this was due to management remains unclear, but unlike ISC, authority at the PEDP grew increasingly diffuse. No scientist/manager emerged to integrate the federal and university interests. Consequently, the federal research program never capitalized on the university's resources, nor did the university benefit from the federal program. When the government terminated the contract, the PEDP was shut down and the physics department resumed its prewar agenda. In contrast, neither the research nor the associated departments at ISC ever returned to their prewar program, structure, or status. The solicited research program left an indelible print on the associated science departments and the college. 
Copyright of Annals of Iowa is the property of State of Iowa, by \& through the State Historical Society of Iowa and its content may not be copied or emailed to multiple sites or posted to a listserv without the copyright holder's express written permission. However, users may print, download, or email articles for individual use. 